\title{
Correction to: Effects of transversus abdominis plane block versus quadratus lumborum block on postoperative analgesia: a meta-analysis of randomized controlled trials
}

\author{
Yanqing Wang ${ }^{1 \dagger}$, Xiaojia Wang ${ }^{2 \dagger}$ and Kexian Zhang ${ }^{1 *}$
}

\section{Correction to: BMC Anesthesiology 20, 103 (2020) https://doi.org/10.1186/s12871-020-01000-2}

Following publication of the research article [1], we have been notified that some values were given incorrectly. In the section "Abstract-Results" stated that: the number of patients requiring analgesia postoperatively (WMD $=3.893,95 \% C I: 2.053$ to $5.733, P<0.001$ ), this values are incorrect and should be expressed as follows: $\mathrm{WMD}=2.618,95 \% \mathrm{CI}: 2.040$ to $3.361, P<0.001$. In the section "Results-Overall meta-analysis" stated that: the number of patients requiring analgesia postoperatively (WMD $=3.893,95 \% \mathrm{CI}: 2.053$ to $5.733, P<0.001$ ), this values are incorrect and should be expressed as follows: $\mathrm{WMD}=2.618,95 \% \mathrm{CI}: 2.040$ to $3.361, P<0.001$. In the section "Results-VAS score at $24 \mathrm{~h}$ postoperatively" stated that: high-quality (WMD $=0.576,95 \% \mathrm{CI}$ : 13.594 to $39.558, P<0.001$ ), this values are incorrect and should be expressed as follows: WMD $=0.576,95 \% \mathrm{CI}$ : 0.048 to $1.104, P=0.032$.

\begin{abstract}
Author details
'Department of Anesthesiology, Sichuan Cancer Hospital \& Institute, SichuanCancer Center, School of Medicine, University of Electronic Science andTechnology of China, No.55, Section 4, South Renmin Road, Chengdu 610041, People's Republic of China. ${ }^{2}$ Department of Pain management, WestChina Hospital, Sichuan University, Chengdu 610041, People's Republic of China.
\end{abstract}

Published online: 27 May 2020

\section{Reference}

1. Wang $Y$, et al. Effects of transversus abdominis plane block versus quadratus lumborum block on postoperative analgesia: a meta-analysis of randomized controlled trials. BMC Anesthesiol. 2020;20(1):103. https://doi.org/10.1186/ s12871-020-01000-2.

The original article can be found online at https://doi.org/10.1186/s12871020-01000-2.

* Correspondence: kxzhangdoctor@hotmail.com

'Yanqing Wang and Xiaojia Wang contributed equally to this work.

'Department of Anesthesiology, Sichuan Cancer Hospital \& Institute, SichuanCancer Center, School of Medicine, University of Electronic Science andTechnology of China, No.55, Section 4, South Renmin Road, Chengdu 610041, People's Republic of China

Full list of author information is available at the end of the article

(c) The Author(s). 2020 Open Access This article is licensed under a Creative Commons Attribution 4.0 International License, which permits use, sharing, adaptation, distribution and reproduction in any medium or format, as long as you give appropriate credit to the original author(s) and the source, provide a link to the Creative Commons licence, and indicate if changes were made. The images or other third party material in this article are included in the article's Creative Commons licence, unless indicated otherwise in a credit line to the material. If material is not included in the article's Creative Commons licence and your intended use is not permitted by statutory regulation or exceeds the permitted use, you will need to obtain permission directly from the copyright holder. To view a copy of this licence, visit http://creativecommons.org/licenses/by/4.0/ The Creative Commons Public Domain Dedication waiver (http://creativecommons.org/publicdomain/zero/1.0/) applies to the data made available in this article, unless otherwise stated in a credit line to the data. 